\title{
POGLACDY JANA STANISŁAWA ŁOSIA NA KWESTIĘ GALICYJSKIEJ MNIEJSZOŚCI UKRAIŃSKIEJ W DRUGIEJ RZECZYPOSPOLITEJ
}

$\mathrm{P}$

olityka władz Drugiej Rzeczypospolitej w stosunku do mniejszości ukraińskiej pozostawiała wiele do życzenia - przypomnieć wystarczy pacyfikację z 1930 r., likwidowanie szkół ukraińskich na rzecz polskich, czy też pomijanie Ukraińców przy przyjmowaniu na państwowe posady. Może to wywołać wrażenie, że odrodzona Polska była nieprzychylna ukraińskości. Jest to osąd mylny, ponieważ na polu polityki i publicystyki polskiej działało grono osób zajmujących się sanacją stosunków polsko-ukraińskich.

Jedną z nich był Jan Stanisław hrabia Łoś (18901974), w latach dwudziestych pracownik Ministerstwa Spraw Zagranicznych, dyplomata, wypowiadający się szczególnie aktywnie na temat kwestii ukraińskiej w latach trzydziestych, kiedy, zwolniony ze służby, włączył się w prace obozu skupionego wokół takich pism jak "Biuletyn Polsko-Ukraiński” czy „Bunt Młodych”. Publicyści ci byli zwolennikami idei sojuszu Rzeczypospolitej z wolną Ukrainą, która miałaby powstać w wyniku rozbicia Związku Sowieckiego. By jednak sojusz taki był możliwy, należało wpierw poprawić złe położenie Ukraińców w Polsce, poprzez poczynienie pewnych ustępstw wobec nich, gdyż wzmocniłoby to Rzeczpospolitą i wzbudziło ufność Ukraińców do niej².

Podobne poglądy dotyczące sprawy ukraińskiej przejawiał Stanisław Łoś w swoich artykułach prasowych i publikacjach książkowych oraz w prywatnych notat-

Mgr Paulina KUSZ jest doktorantką przy Katedrze Dziejów Systemów Totalitarnych Instytutu Historii Katolickiego Uniwersytetu Lubelskiego Jana Pawła II. pkusz@kul.lublin.pl

1 Artykut jest skróconą wersją pozycji: P. Kusz, Jan Stanisław Łoś wobec kwestii ukraińskiej (1918-1939). Analiza myśli spoteczno-politycznej, Lublin 2010.

2 W. Mich, Problem mniejszości narodowych w myśli politycznej Polskiego Ruchu Konserwatywnego (19181939), w: Mniejszości narodowe w polskiej myśli politycznej XX wieku, Lublin 1992, s. 92-93; idem, Problem mniejszości narodowych w myśli politycznej Polskiego Ruchu Konserwatywnego (1918-1939), Lublin 1992, s. 47-50, 189-190, 195-198. 
kach. Zajmując się wyłącznie mniejszością ukraińską Galicji Wschodniej, a więc województw Iwowskiego, tarnopolskiego i stanisławowskiego, hrabia akcentowat, iż szczególnego uzdrowienia wymaga szkolnictwo ukraińskie oraz gospodarka tego terenu, a także ogólna linia polityki prowadzonej wobec Ukraińców przez państwo polskie.

Ważkim problemem dla społeczeństwa ukraińskiego był utrakwizm, czyli system szkolnictwa dwujęzycznego, wprowadzony w 1924 r. na mocy tzw. ustaw językowych Stanisława Grabskiego. Teoretycznie miał on służyć zbliżeniu polsko-ukraińskiemu, a w praktyce stanowił narzędzie wynaradawiania, przez odcinanie Ukraińców od ojczystego języka³. Ostro przeciw takim rozwiązaniom występował Stanisław Łoś, który przekreślał możliwości asymilacyjne szkoły, przypominając, że gdyby było inaczej, naród polski już by nie istniał w wyniku działań szkół rosyjskich lub pruskich. Według publicysty asymilacja mniejszości ukraińskiej byłaby możliwa, gdyby przewidziana była nie na kilka lat, a na sześćdziesiąt lub sto. Łoś nie wierzył przy tym w siłę jawnej asymilacji, której zwolennikami byli polscy politycy. Powtarzał, że

\begin{abstract}
„asymilacja, to nie jest jakaś czynność podobna do czynności jedzenia. Asymilacja to jest proces, który przechodzi asymilowany. Proces, który by normalnie mógł się dokonać, wymaga nieświadomości po stronie tak asymilującego jak i asymilowanego; zwrócenie jego uwagi na przemianę której podlega, przerywa ją zazwyczaj bezpowrotnie. [...] Dlatego to wszelka polityka, która na swym sztandarze jawnie wypisała hasło asymilacji nigdy jeszcze w ciągu historii nie została uwieńczona powodzeniem"4.
\end{abstract}

Publicysta słusznie zauważał, że agresywna polonizacja wzmagała czujność i opór Ukraińców, odstręczając ich od państwa polskiego, jako asymilatora. Władze polskie nie miały przy tym prawa działać przeciw narodowi ukraińskiemu i oczekiwać, że po kilkunastu latach w Galicji Wschodniej mieszkać będą tylko Polacy ${ }^{5}$.

Poznawanie kultury i języka polskiego wcale nie zaszczepiało w Ukraińcach miłości do Rzeczypospolitej, przeciwnie - sprowadzało ich na drogę nienawiści do niej. Łoś uważał, że wyższa od ukraińskiej kultura polska, wpajana na siłę, wywoływała u Ukraińców niebywałą niechęć. Wobec takiego stanu rzeczy był przeciwny przymuszaniu ukraińskich uczniów do nauki języka polskiego. Najlepsza byłaby sytuacja, gdyby rodzice uważali znajomość języka państwowego za cenne dobro i gdyby sami pragnęli, bez jakiejkolwiek ingerencji władz, aby ich dzieci się go uczyły. W przeciwnym wypadku, wobec negatywnej postawy rodziców, szkoła nie byłaby w stanie niczego zdziałać, ponieważ w walce z domem rodzinnym zawsze skazana jest na porażkę

Hrabia Łoś dowodzit, że utrakwizm drażnił uczucia narodowe Ukraińców galicyjskich i stanowił pożywkę dla rozwijającego się ruchu nacjonalistycznego. Szczególnie niedopuszczalny był na poziomie szkół średnich, ponieważ nakaz nauki języka polskiego wzmagał ukraiński nacjonalizm, kiełkujący najobficiej w sercach młodzieży. Publicysta ubolewał, że młodzi Ukraińcy uczą się z polskich książek. Ostrzegał przed dalszymi takimi praktykami. Był przekonany, iż ci sami chłopcy, którzy zmuszani byli do czytania po polsku, buntując się, wstępowali do nielegalnych organizacji ukraińskich. Ferment wśród młodzieży ukraińskiej w szkołach utrakwistycznych mógł też być spowodowany przez konieczność

\title{
-.....
}

S. Mauersberg, Oświata, w: Polska Odrodzona 1918-1939. Państwo - społeczeństwo - kultura, red. J. Tomicki, wyd. 2, Warszawa 1988, s. 531.

4 S. Łoś, O konstruktywną politykę na Rusi Czerwonej, Warszawa 1932, s. 19.

5 Ibidem, s. 20; Archiwum Państwowe w Lublinie [APL], Archiwum Łosiów z Niemiec [AŁ], sygn. 473, S. Łoś, Sprawa ukraińska w polityce polskiej [rps, bd], k. 28-29.

6 APL, At, sygn. 473, S. Łoś, Uwagi o polityce szkolnej na terenie trzech województw południowo-wschodnich [rps, bd], k. 32; S. Łoś, O konstruktywną politykę..., s. 19-22. 
podawania jednego wydźwięku danego wydarzenia historycznego albo dzieła literackiego. Wydźwięk ten, powodowany przecież polską racją stanu, był zawsze propolski.

Były jednak dwie sytuacje, kiedy Stanisław Łoś dopuszczał utrakwizm. Czynit to w odniesieniu do najniższego poziomu szkolnictwa mniejszości ukraińskiej, wyłącznie na terenach, gdzie ludność była rzeczywiście dwujęzyczna, a dzieci uczęszczające do szkoły pochodziły z małżeństw mieszanych. Takie rozwiązanie przynosiło uzasadnioną korzyść - kilkuletniemu dziecku nie narzucano narodowości, a pozwalano mu ją wybrać później, kiedy dorośnie i będzie znało kulturę obu swych ojczyzn . Druga sytuacja dotyczyła seminariów nauczycielskich, które kształciły nauczycieli do szkół jedno- i dwujęzycznych. Było to słuszne stwierdzenie w obliczu reformy szkolnictwa Janusza Jędrzejewicza z 1932 r., kiedy wycofano z liceów pedagogicznych język ukraiński, przez co spadła liczba jego nauczycieli9.

Zamiast utrakwizmu Stanisław Łoś wysuwał pomysł szkolnego paralelizmu, czyli istnienia w Galicji Wschodniej, obok siebie, szkół obu narodowości. Ukraińcy powinni mieć prawo do własnych szkół i pielęgnowania swej tradycji i kultury. W programach szkolnych należało uwzględnić bohaterów (np. Jarosława Mądrego, Daniela Halickiego, Herburtów, Sobieskich) i historię tej ziemi, czyli dawnego księstwa włodzimiersko-halickiego, uczyć ukraińskich pieśni, szczególnie tych patriotycznych z Szcze ne wmerła Ukrajina na czele, nie odżegnywać się od kolorów "sino-żółtych”. Słowem, trzeba było podsycać "narodowe uczucie ukraińskie" - rzecz jasna tak, by nie zaszkodziło to państwu polskiemu. Wszystko po to, by uświadomić młodym Ukraińcom, że żyją we własnym państwie, we własnej dzielnicy i że powinni być z tego dumni. Dobrze byłoby wykazać im też, że choć różnią się od Polaków pod względem języka, to "rasowo" są z nimi identyczni10.

Stanisław Łoś, prócz usunięcia utrakwizmu, był za zmianą całego systemu szkolnictwa polskiego. Ten wymagał korekty, ponieważ nie dość, iż nie sprzyjał przyjaźni między Polakami a przedstawicielami mniejszości narodowych, to, co gorsza, wypuszczał na rynek zbyt dużo fachowców o nieprzydatnych profesjach.

Według publicysty tereny Galicji Wschodniej potrzebowały specjalistów z dziedziny rolnictwa. Mawiał, że produkcja inteligencji przestała mieć sens, ponieważ już było jej za dużo. Postulował więc skierowanie ukraińskiej młodzieży do zawodów rolniczych. W tym celu należało stworzyć odpowiednie szkoły - liceum rolnicze i szkołę nauk handlowo-gospodarczych. Hrabia pragnąt, by powstała Ukraińska Akademia Gospodarcza, w związku z powolną degradacją placówki o tej samej nazwie w Podiebradach w Czechosłowacji. Państwo polskie nie miało funduszy na taką uczelnię. Stanisław Łoś nie poddał się jednak - był propagatorem i opiekunem pomysłu utworzenia Państwowego Liceum Rolniczego z Ukraińskim Językiem Nauczania w Czernyci (woj. stanisławowskie). Szkoła powstała w latach 1935-1937. Możliwość stworzenia liceum rolniczego publicysta postrzegat jako wkład w zbliżenie obu narodowości Galicji Wschodniej¹.

\section{- - - •}

Ibidem, s. 23; S. Łoś, Po oświadczeniu UNDO i UPR, „Czas”, 26 VII 1934, APL, At, sygn. 472, k. 13; APL, AŁ, sygn. 473, S. Łoś, Uwagi o polityce szkolnej na terenie trzech województw południowo-wschodnich, k. 33.

8 Ibidem, k. 32; S. Łoś, O konstruktywną politykę..., s. 23.

9 Ibidem, s. 24-25; S. Mauersberg, Szkolnictwo powszechne dla mniejszości narodowych w Polsce w latach 1918-1939, Wroctaw 1968, s. 95-96, 100.

10 APL, At, sygn. 473, S. Łoś, Uwagi o polityce szkolnej na terenie trzech województw południowo-wschodnich, k. 33

11 S. Łoś, O konstruktywną politykę..., s. 27; APL, AŁ, sygn. V-1, t. 1, S. Łoś, Uwagi odnośnie do traktowania zagadnienia ukraińskiego w Polsce, w szczególności na terytorium województwa lwowskiego, stanisławowskiego i tarnopolskie[go] w latach najbliższych [mps, bd], k. 295-296; APL, AŁ, sygn. V-1, t. 1, S. Łoś [rps, b.t.], k. 191, 196; S. Łoś, Ukraińskie Liceum Rolnicze, "Czas”, 13 X 1934, APL, At, sygn. 472, k. 15; APL, At, sygn. V-1, t. 1, List od Chrapływego (b.m. 16 III 1934), k. 359. 
Stanisław Łoś dostrzegał również potrzebę powstania ukraińskiej wyższej szkoły humanistycznej. O jej utworzenie apelował przez całe dwudziestolecie międzywojenne, dokładając starań dla realizacji tego projektu. Najczęściej i z największym rozgoryczeniem wspomniał straconą szansę z 1924 r., której był pomysłodawcą ${ }^{12}$. Uniwersytet miał mieć ukraińską kadrę i nosić imię króla Daniela. Tak się jednak nie stało za sprawą ukraińskich działaczy politycznych i społecznych. Mimo tej porażki publicysta, do końca lat trzydziestych przypominał o konieczności utworzenia „humanistyczno-historycznej wyższej szkoły ukraińskiej". Należałoby ją erygować na terenach o wysokim odsetku ludności ukraińskiej, a więc koniecznie w Galicji Wschodniej, i wyposażyć w starannie dobraną kadrę narodowości ukraińskiej. Na uniwersytecie powinny być wykładane i rozwijane wszelkie nauki poświęcone narodowemu życiu Ukraińców, tak by stworzyć szkołę politycznego i historycznego myślenia. Uczelnia miała być, według Łosia, podstawową pomocą w wytwarzaniu wśród Ukraińców właściwego stosunku do państwa polskiego oraz jednym z punktów dobrej polityki rządu wobec tej mniejszości narodowej ${ }^{13}$.

Uniwersytet ukraiński byłby mostem dla porozumienia polsko-ukraińskiego. Wspornikiem tego mostu miało być natomiast nauczycielstwo ukraińskie, co było pomysłem innowacyjnym. Ta grupa zawodowa, przez Łosia oceniana na około 4 tys. osób, była odpowiednia do tego, by po przygotowaniu propagandowym przekonać społeczeństwo ukraińskie do państwa polskiego. Publicysta miał na uwadze szczególnie tych pedagogów, których za nielojalność w stosunku do państwa przeniesiono w głąb Polski i bezskutecznie usitowali oni wrócić do Galicji Wschodniej. Planował wybrać z tego grona odpowiednie jednostki i z obietnicą przeniesienia ich w rodzinne strony poddać „politycznemu przeszkoleniu". Kurs trwałby od trzech do pięciu tygodni, a składałby się z następujących wykładów historycznych: historia Ukrainy-Rusi, historia unii kościelnej, historia stosunków polsko-ukraińskich ${ }^{14}$. Wygłaszane byłyby one w języku polskim i ukraińskim przez przedstawicieli obu narodowości. Wśród audytorium powinno znajdować się również około 25\% nauczycieli narodowości polskiej, aby służyć przykładem, że możliwe jest zgodne współżycie polsko-ukraińskie. Działania takie hrabia bez ogródek nazywał „bezpośrednią żywą propagandą". Brał pod uwage jej niepowodzenie, jednak bardziej wierzył, że wyda oczekiwane owoce. Miał nadzieję, iż pomoże ona przekonać ukraińskich nauczycieli, że będąc ukraińskimi patriotami, nie muszą nienawidzić państwa polskiego. Chciał też, by jako propolsko uformowana grupa przekonali władze Rzeczypospolitej, że Ukraińcy galicyjscy mogą bez uszczerbku dla państwa polskiego rozwijać się jako naród posiadający misję podtrzymania kultury ukraińskiej, która w Związku Radzieckim była niszczona ${ }^{15}$.

Równie energicznie Jan Stanisław Łoś wypowiadał się w sprawach gospodarczych. Bolączką Galicji Wschodniej były słabe gleby oraz katastroficzny głód ziemi, dotykający i Ukraińców, i Polaków. Sytuacji nie polepszał narastający od końca lat dwudziestych kryzys ekonomiczny. Publicysta starał się wysuwać odpowiednie rozwiązania w tej kwestii, poczynając od reformy rolnej, na urbanizacji ludności ukraińskiej kończąc.

\section{-.....}

12 Potwierdza to Leonid Zaszkilniak, zob. idem, Ukrajins'ko-pols'ke porozuminnia 1935 r. (za materiałamy archiwu Ja. C. Łosia), „Probłemy Stowianoznawstwa. Miżnarodnyj Naukowyj Zbirnyk” 1996, nr 48, s. 65.

$13 \mathrm{APL}, \mathrm{At}$, sygn. V-1, t. 1, S. Łoś, Uwagi odnośnie do traktowania zagadnienia ukraińskiego w Polsce..., k. 293; S. Łoś, Odpowiedź na ankietę "Biuletynu» "Biuletyn Polsko-Ukraiński”, nr 4 (243), 23 I 1938, s. 24; APL, At, sygn. 473, S. Łoś, Uwagi o polityce szkolnej na terenie trzech województw południowo-wschodnich, k. 34.

14 W 1932 r. Łoś planował również zorganizowanie cyklu wykładów na temat polskiej i ukraińskiej racji stanu. Wykłady te odbyłyby się we Lwowie, Przemyślu, Stanisławowie, Tarnopolu, Kołomyi. Sam hrabia wygłaszałby zawsze ostatni wykład cyklu, APL, At, sygn. 355, List do Ministra (Niemce, 26 IV 1932), k. 135.

$15 \mathrm{APL}, \mathrm{A}$, sygn. 356, Memoriał S. Łosia w sprawie politycznego przeszkolenia nauczycieli szkół powszechnych narodowości ukraińskiej (9 VI 1932) [mps], k. 12-15; APL, AŁ, sygn. 355, S. Łoś, Aide-memoire [mps, bd], k. 15. 
Reforma rolna realizowana w Polsce od 1920 r. mijała się z zapatrywaniem hrabiego na ten temat, a przy tym nie przynosiła satysfakcji większej masie chłopskiej. Stanisław Łoś zwrócił uwage, że prawidłowo przeprowadzona reforma rolna powinna być rozłożona na lat kilkanaście, oraz że nie mogła być przeprowadzana od razu w skali całej Galicji Wschodniej, jak i ograniczona tylko do parcelacji. W innym wypadku Stanisław Łoś przewidywał zaostrzenie się problemów społecznych i narodowościowych, silną urbanizację i proletaryzację chłopów, a co za tym idzie, możliwe zagarnięcie ich przez ruch komunistyczny ${ }^{16}$.

Według hrabiego, na właściwie pojętą reformę rolną składały się: parcelacja, komasacja, likwidacja wspólnot, oddłużenie resztówek (pozostałości po wywłaszczonym folwarku), podtrzymywanie rentowności folwarków ${ }^{17}$.

W sprawie parcelacji Stanisław Łoś sporo miejsca poświęcił rozważaniom na temat klucza podziału w przyznawaniu ziemi Polakom i Ukraińcom. Publicysta podał, że rząd polski, przy pominięciu kolonistów, przewidział 75\% parcelowanej ziemi na rzecz Polaków, pozostawiając 25\% Ukraińcom. Ci zaś zaproponowali, by Polacy dostali 60\%, im samym przypadłoby wówczas 40\%. Hrabia przypomniał w tym miejscu, że w Galicji Wschodniej mieszkała ludność mieszana narodowościowo i często było trudno ustalić nację poszczególnych jednostek, a z nazywaniem rzymskich katolików Polakami, a grekokatolików Ukraińcami stanowczo się nie zgadzał, twierdząc, że ani język, ani wiara nie warunkują narodowości. Wobec tego faworyzowanie rzymskich katolików nie miałoby sensu, gdyż tylko formalnie popierano by przez to polskość. Choćby Polacy dostali nawet 3/4 rozparcelowanej ziemi, to na drodze małżeństw mieszanych oraz spadków, już w ciągu jednego pokolenia Iwia jej część przeszłaby w ręce grupy silniejszej liczebnie, czyli Ukraińców ${ }^{18}$. Hrabia postulował więc przyjęcie racjonalnego podziału procentowego ziemi, mniej dla Polaków korzystnego. Czynił tak nie dlatego, by wzmocnić Ukraińców, a po to, by uniknąć sytuacji, w której Polacy nie radzą sobie z ilością przeznaczonej dla nich ziemi, oraz z zaciągniętymi na ten cel kredytami i odsprzedają ziemię Ukraińcom, stając się handlarzami-spekulantami ${ }^{19}$.

Ponieważ Stanisław Łoś w swych planach dążył do osłabienia pozycji Ukraińców, by wzmocnić Polaków, wprowadzit do swego projektu osadników. Pierwszy pomysł Łosia oparty był na szczegółowych obliczeniach areału do podziału, mianowicie sięgał on 370 tys. ha. Łoś planowat, że działki z tej puli dostaną wszyscy miejscowi Polacy oraz 25\% Ukraińców. Pozostanie 37\% ziemi, czyli 100 tys. ha do podziału między kolonistów, których teren w takim wypadku mógtby przyjąć w liczbie około 100 tys. Odsetek Polaków wzrósłby więc o 3-4\% ${ }^{20}$. W pomyśle drugim, ziemię tego regionu Łoś proponował podzielić na trzy kontyngenty: pierwszy dla osadników (25\% rozparcelowanej ziemi), drugi dla miejscowych chłopów ukraińskich (również 25\% ziemi), a trzeci dla miejscowych chłopów polskich (tu 50\% ziemi). Do chłopów polskich hrabia zaliczał również małżeństwa mieszane, które według jego obliczeń stanowiły aż 16\% wszystkich małżeństw w dzielnicy. Przeznaczyłby im 10\% zapasu „polskiej” ziemi. Wedle tych propozycji osadnictwo

\section{$\cdots \cdots$}

16 APL, AŁ, sygn. V-1, t. 2, S. Łoś, E. Lipski, Rozwinięcie i uzasadnienie "Tez, na których należałoby oprzeć politykę agrarną na Południowym-Wschodzie" [mps, bd], k. 63; APL, At, sygn. V-1, t. 2, S. Łoś, Reforma rolna na Południowym-Wschodzie [rps, bd], k. 95.

$17 \mathrm{APL}, \mathrm{At}$, sygn. V-1, t. 2, S. Łoś, Tezy, na których należałoby oprzeć politykę agrarną na PołudniowymWschodzie [mps, bd], k. 51; A. Bocheński, S. Łoś, W. Bączkowski, Problem polsko-ukraiński w Ziemi Czerwieńskiej, Warszawa 1938, s. 207.

18 Według obliczeń hrabiego udział Polaków w populacji Galicji Wschodniej wynosił od 28 do 35\%, wobec tego Ukraińcy stanowili najmniej $65 \%$ tej ludności, APL, At, sygn. V-1, t. 2, S. Łoś, E. Lipski, Rozwinięcie i uzasadnienie "Tez..., k. 54.

19 APL, At, sygn. 473, S. Łoś, Reforma rolna na Południowym Wschodzie [rps], k. 18-19.

20 APL, AŁ, sygn. V-1, t. 1, S. Łoś, Reforma rolna na Południowym-Wschodzie, k. 94-95. 
dałoby 2-3\% wzrostu ludności polskiej, a polonizacja w małżeństwach mieszanych $5 \%$. Zysk byłby więc wyższy, wyniósłby 7-8\% ${ }^{21}$.

Jeżeli chodzi o kolejne aspekty reformy rolnej, to komasacja, czyli scalenie gruntów, oraz likwidacja wspólnot pozwoliłyby, według Stanisława Łosia, na wytworzenie się skupisk ludności polskiej, wsi lub przysiółków, na tyle silnych, by mogły utrzymywać kościół, szkołę, sklep, mleczarnię itd. Nie tylko wzmocniłoby to żywioł polski w Galicji, ale też przyczyniłoby się do asymilacji niezdecydowanych narodowościowo. Również oddłużenie resztówek byłoby korzystne, ponieważ były one nośnikami polskości, dowodem dla chłopa ukraińskiego, że jego symbioza z dworem przynosi mu zysk ${ }^{22}$.

Ważną, i trochę sentymentalną, dla hrabiego kwestią było podtrzymanie żywotności folwarków. Wspominat o tym często, podając liczne argumenty. Uchwalona reforma rolna przewidywała częściową kasację folwarków, które przecież w większości należały do Polaków, ale Łoś był temu przeciwny. Uważał je bowiem za zjawisko pożyteczne na ziemiach Galicji Wschodniej, wysuwał więc wobec nich plan mniej restrykcyjny od idei rządowej. Należałoby zlikwidować około 30\% ziemi folwarcznej, ze względu na jej zadłużenie. Reszta ziemi pozostającej przy folwarku powinna była być już nieobciążona zobowiązaniami pieniężnymi. Nie warto niszczyć majątków silnych, a wręcz należałoby dbać o ich rentowność. Profity z utrzymania folwarków były przynajmniej dwojakie. Posiadacz ziemski dzięki zadzierzgniętej z dawien dawna symbiozie z małorolnymi mógł wywierać na nich wpływ dużo silniejszy niż organa rządowe. Dwór polski był przy tym rozsadnikiem polskości, wzbudzając sympatię, miał większą łatwość w asymilacji chłopów ukraińskich ${ }^{23}$. Natomiast małorolne i karłowate gospodarstwa czerpały z dorywczej pracy na folwarku niezaprzeczalne zyski. Dzięki pracy na polach folwarku gospodarze stawali się niejako gospodarzami pełnorolnymi, ponieważ dostawali potrzebne im produkty. W przypadku, gdyby folwark się rozpadt, chłop musiałby walczyć o ziemię, która czyniła go do tej pory pełnorolnym. Jeśli, na przykład, gospodarz ukraiński nie dostałby wystarczająco dużo nadziału, przegrywając z miejscowym lub nowo przybyłym Polakiem, karłowatość jego gospodarstwa stałaby się rzeczywistą. Chłop tolerował potentata ziemskiego, ale kolonizatora znienawidzitby. Konkludując, oderwanie od majątków folwarcznych zbyt dużych połaci ziemi pociągnęłoby za sobą tylko pauperyzację ludności i zaognienie stosunków narodowościowych²4.

Z reformą rolną związek miała również akcja osadnicza wojskowych i cywilów na Wotyniu i w Galicji Wschodniej, której szczyt przypadł na lata 1921-1924. Kolonizacja, której celem było wzmocnienie polskości, nie przyniosła pozytywnych efektów, a zaostrzyła tylko stosunki narodowościowe, ponieważ ludność niepolska czuła się pokrzywdzona nierównym podziałem ziemi między nią a przybyszów ${ }^{25}$.

Stanisław Łoś był gorliwym przeciwnikiem masowej kolonizacji. Uważał, że wzmocnienie żywiołu polskiego na jej drodze byłoby zwyczajnie niemożliwe, a przy tym wymagałoby dużych nakładów pieniężnych oraz groziłoby zachwianiem i tak nadwyrężonego

21 APL, At, sygn. V-1, t. 2, S. Łoś, Tezy, na których należałoby oprzeć politykę agrarną..., k. 51; APL, At, sygn. V-1, t. 2, S. Łoś, E. Lipski, Rozwinięcie i uzasadnienie „Tez..., k. 60.

22 Ibidem, k. 62

23 "Uczucia chłopa ukraińskiego do polskiego nauczyciela, tacińskiego proboszcza i komendanta policji [...] nie bywają normalnie bardzo ciepłe, jedynie ziemianin może w pewnych warunkach być jako tako popularny", A. Bocheński, S. Łoś, W. Bączkowski, op. cit., s. 206; APL, AŁ, sygn. V-1, t. 2, S. Łoś, E. Lipski, Rozwinięcie i uzasadnienie "Tez..., k. 60.

24 Ibidem, s. 204; APL, AŁ, sygn. V-1, t. 1, k. 10; APL, AŁ, sygn. V-1, t. 2, S. Łoś, E. Lipski, Rozwinięcie i uzasadnienie „Tez..., k. 56; S. Łoś, Reforma rolna na południowym wschodzie, "Bunt Młodych", 10.04.1936, APL, At, sygn. V-1, t. 1, k. 100.

25 M. Papierzyńska-Turek, Sprawa ukraińska w Drugiej Rzeczypospolitej 1922-1926, Kraków 1979, s. 29-34; R. Torzecki, Kwestia ukraińska w Polsce w latach 1923-1929, Kraków 1989, s. 106. 
zaufania Ukraińców do władz i polskich sąsiadów. Słuszne było jego przekonanie, że niedostatek ziemi oraz nadwątlona struktura rolna Galicji Wschodniej nie sprzyjała tego typu działaniom. Hrabia przypominał w tym miejscu, że racjonalniej i bezpieczniej byłoby wychowywać lojalnych wobec państwa ukraińskich chłopów, niż importować polskich z głębi kraju ${ }^{26}$. Negował przy tym możliwość spektakularnego powiększenia odsetka Polaków zamieszkujących Galicję Wschodnią dzięki kolonizacji, podając różne cyfry, jednak nie bardzo rozbieżne - od 1 do $6 \%{ }^{27}$.

Jak widać, hrabia Łoś generalnie był przeciwny kolonizacji, jednak dopuszczał ją w uzasadnionych przypadkach, m.in. tam, gdzie istniał jeszcze pewien zapas ziemi oraz gdzie odsetek Polaków byłby podobny do odsetka Ukraińców. Osadnicy potrzebni byliby szczególnie w bliskich okolicach dużych miast Galicji Wschodniej, takich jak Lwów czy Tarnopol, aby ośrodki te miały możliwość wchłaniania polskiej ludności. Największą nadzieję publicysta pokładał jednak w funkcji obronnej, jaką spełniałaby kolonizacja napływowymi Polakami, rozlokowanymi w paru punktach przy granicy. Punktów tych jednak nie można było utworzyć za dużo, gdyż osłabiłoby to osiągnięte wyniki. By odpowiednio spełniać swe funkcje, takie skupiska Polaków musiałyby być przy tym zaopatrzone we wszystkie instytucje kulturalne i gospodarcze potrzebne do podtrzymywania polskości. Stanisław Łoś proponował również "kolonizację ruską", czyli przesiedlanie Ukraińców z zachodnich powiatów województwa Iwowskiego do wschodniej jego części, czyli powiatów w zasadzie czysto ukraińskich. Większe byłyby wówczas szanse na spolonizowanie lewej strony Sanu, na co liczył Łoś28.

Wynikiem nierównego podziału ziemi spowodowanego reformą rolną oraz kolonizacją była narastająca urbanizacja ludności ukraińskiej. Chłopi, którym nie udało się powiększyć swego stanu posiadania lub nawet stracili z powodu rozpadu własności folwarcznej, zmuszeni byli szukać alternatywnego środka zarobkowania. Również dzieci gospodarzy rolnych, które nie dostały w spadku nadziału ziemi z rozdrobnionego gospodarstwa rodziców, wyruszały za chlebem do miast. Hrabia rozumiał, że przenoszenie się chłopów do miast jest nieuniknione, ponieważ wieś galicyjska była jedną z najbardziej przeludnionych w państwie. Tym bardziej ubolewat, iż korzystniejszy dla ludności polskiej rozdział ziemi doprowadzał do przekazania pierwszeństwa w procesie urbanizacyjnym ludności ukraińskiej. Pozbawieni ziemi Ukraińcy mieli większą potrzebę i motywację, by przenosić się do miast, podczas gdy Polacy pozostawali na wsi. Stanisław Łoś obawiał się wobec tego „zruszczenia” miast Galicji Wschodniej, co było tym bardziej niebezpieczne, że miasta tego regionu stanowiły „enklawę polskości”. Dlatego też trzeba było mieć na uwadze, by Ukraińcy mieszkający w miastach nie przeważyli liczebnie nad Polakami, a także należało utrzymać w ryzach żywiołowy proces urbanizacyjny ${ }^{29}$.

Łoś postulował, by uwzględnić potrzeby rolne Ukraińców tak, by zmniejszyła się liczba emigrujących ze wsi. Nie warto byłoby mimo to utrudniać im przenoszenia się do miast. Według hrabiego znaleźliby oni tam zatrudnienie przede wszystkim w przemyśle, rzemio-

\section{- ...}

26 APL, At, sygn. V-1, t. 2, S. Łoś, Reforma rolna na Południowym-Wschodzie, k. 95; APL, At, sygn. V-1, t. 1, S. Łoś, Uwagi odnośnie do traktowania zagadnienia ukraińskiego w Polsce..., k. 296; S. Łoś, Reforma rolna na południowym wschodzie, "Bunt Młodych”, 10 IV 1936, APL, At, sygn. V-1, t. 1, k. 100.

27 1-2\%, patrz: APL, At, sygn. V-1, t. 1, S. Łoś, [rps, b.t.], k. 20; 2-3\%, patrz: A. Bocheński, S. Łoś, W. Bączkowski, op. cit., s. 203; 5\%, patrz: S. Łoś, Reforma rolna na południowym wschodzie, "Bunt Młodych", 10 IV 1936, APL, At, sygn. V-1, t. 1, k. 100; 6\%, patrz: APL, AŁ, sygn. V-1, t. 2, S. Łoś, E. Lipski, Rozwinięcie i uzasadnienie „Tez..., k. 54.

28 A. Bocheński, S. Łoś, W. Bączkowski, op. cit., s. 203; APL, At, sygn. V-1, t. 2, S. Łoś, E. Lipski, Rozwinięcie i uzasadnienie „Tez..., k. 60-61; APL, At, sygn. V-1, t. 1, k. 14; APL, AŁ, sygn. 473, S. Łoś, Reforma rolna na Południowym Wschodzie, k. 14.

29 A. Bocheński, S. Łoś, W. Bączkowski, op. cit., s. 201-202, 205; APL, At, sygn. V-1, t. 1, S. Łoś, [rps, b.t.], k. 11. 
śle, handlu, niekiedy w wolnych zawodach. By mieć wpływ na tworzącą się ukraińską warstwę mieszczańską i prowadzić ją do współpracy z analogiczną warstwą polską, Łoś popierał powstawanie w miastach Galicji Wschodniej organizacji ukraińskich. Korzystnym byłoby przy tym stworzenie rezerwuaru ludności polskiej, osiedlonej w wyniku kolonizacji, przy dużych ośrodkach miejskich dzielnicy, ponieważ utrzymywałoby to w normie stosunki narodowościowe w miastach ${ }^{30}$. Warto by było też przyspieszyć urbanizację Polaków, na przykład przez zorganizowanie drobnych polskich przedsiębiorstw współpracujących z ukraińskimi. Publicysta krytykował przy tym rozwiązania wysuwane przez władze, tj. wysyłanie do miast Galicji Wschodniej urzędników z głębi kraju, by tym samym zwiększyć odsetek Polaków. Odsetek ten zwiększony byłby wyłącznie na papierze, ponieważ napływowa inteligencja, nie będąc elementem zakorzenionym, równie szybko jak przyjechała, mogłaby wyjechać, natomiast polskość miast dzielnicy stałaby wciąż pod znakiem zapytania ${ }^{31}$.

Znaczącym elementem gospodarczego życia Galicji Wschodniej w okresie międzywojennym była konkurencja polskich i ukraińskich organizacji gospodarczych, przy czym częściej przewage miała strona ukraińska. Publicysta nie pomijał tego w swych wypowiedziach. Skrytykował faworyzowanie kooperatyw polskich w dostępie do grosza publicznego, ponieważ wywołało to efekt odwrotny do zamierzonego. W obliczu światowego kryzysu sztucznie galwanizowane pieniędzmi z budżetu spółdzielnie polskie głęboko odczuwały recesję, podczas gdy organizacje ukraińskie, zmuszone radzić sobie same, stały na zdrowszych podstawach. Władze polskie popełniły jeszcze jeden błąd, uprawiając tak jawną niesprawiedliwość - sprawiły, że Ukraińcy zarządzający spółdzielniami zadłużali się za granicą, np. W III Rzeszy, co prowadziło do uzależnienia się ukraińskiej inteligencji od czynników obcych. Łoś podkreślał więc, że wina za to, iż Galicją rządzą obcy, a jej struktura socjalna i gospodarka są wykoślawione, leży wyłącznie po stronie Polaków³2.

Stanisław Łoś szanował ukraińskie kooperatywy i nie był przeciwny ich istnieniu. Uważał je za zjawisko pożyteczne w skali gospodarczej kraju, jako że powiększały produkt krajowy oraz eliminowały w dużym stopniu z życia gospodarczego Żydów. Żydzi w opinii Łosia powinni być zwalczani, gdyż stanowili niebezpieczną konkurencję dla Słowian w Galicji Wschodniej. Publicysta obliczał, że w obrocie gospodarczym dzielnicy Polacy posiadali 15\% udziału, Ukraińcy - 8\%, a reszta, czyli aż 77\%, należała do Żydów. Korzystniej byłoby nie przeszkadzać Ukraińcom w bogaceniu się, skoro ci nie przeszkadzali Polakom. Organizacje ukraińskie powinny więc rozwijać się własnym trybem, być może z finansową pomocą państwa, ale na pewno nie powinny być likwidowane ani łączone z kooperatywami polskimi. Spajanie polskich i ukraińskich spółdzielni Łoś dopuszczał tylko na terenie na zachód od Sanu, gdzie widział korzyść w dosyć łatwej asymilacji tamtejszych Ukraińców przez codzienne ich przebywanie z Polakami33. Generalnie jednak organizacje te powinny być osobne, ponieważ połączone z pewnością miałyby polskie kierownictwo, a to pociągnęłoby za sobą stworzenie rzeszy bezrobotnej ukraińskiej inteligencji, która do tej pory zajmowała się gospodarką. Z drugiej strony, choć zarząd byłby polski, Łoś przewidywał, że narodowo świadomi Ukraińcy celowo zapełniliby szeregi kooperatywy, przejmując rzeczywistą nad nią kontrolę, co nie byłoby dobre dla żywiołu polskiego, gdyż prawie zostałby on pozbawiony własnych spółdzielni. Zamiast łączyć działające osobno kooperatywy, pub-

\section{......}

30 Ibidem, k. 10; APL, AŁ, sygn. V-1, t. 2, S. Łoś, Tezy, na których należałoby oprzeć politykę agrarną..., k. 49; $\mathrm{APL}, \mathrm{At}$, sygn. V-1, t. 2, S. Łoś, E. Lipski, Rozwinięcie i uzasadnienie „Tez..., k. 61.

31 A. Bocheński, S. Łoś, W. Bączkowski, op. cit., s. 221-223.

32 S. Łoś, O konstruktywną politykę..., s. 28-32.

33 A. Bocheński, S. Łoś, W. Bączkowski, op. cit., s. 213-214; APL, At, sygn. V-1, t. 1, S. Łoś, [rps b.t.], k. 21-20; S. Łoś, O kwestii ukraińskiej, "Biuletyn Polsko-Ukraiński”, nr 13 (252), 27 III 1938, s. 136; APL, At, sygn. V-1, t. 1, S. Łoś, Uwagi odnośnie do traktowania zagadnienia ukraińskiego w Polsce..., k. 290. 
licysta radził, by namawiać je do współpracy, przy zachowaniu ich zupełnej odrębności. Można by było tworzyć parytetowe syndykaty, mające osiągnąć wyznaczone cele. Wypełniając wspólne zadania, organizacje nie ponosiłyby żadnej straty, a pomnażałyby zysk Galicji Wschodniej34

Jan Stanisław Łoś zwracał uwagę na błędne decyzje rządu nie tylko w sprawach oświaty i gospodarki, ale też w kwestii ogólnej linii polityki w stosunku do Ukraińców. W swych pracach ukazywat, że kolejne rządy polskie nie radziły sobie z dużą, stanowiącą około 5-6 mln osób mniejszością narodową, jaką byli Ukraińcy ${ }^{35}$. Stwierdzał, że polityka wszystkich gabinetów w tej kwestii była „mglista, chwiejna, zygzakowata i pełna wewnętrznych sprzeczności"36, a jedynym, który tę sprawę udźwignął, był rząd, w którym ministrem spraw zagranicznych był Aleksander Skrzyński. Wówczas, w 1923 r., Rzeczpospolita uzyskała Galicję Wschodnią bez zobowiązań w zakresie samorządu ${ }^{37}$.

Sam Łoś przez wiele lat walczył o uzdrowienie stosunków polsko-ukraińskich orężem zwanym polską polityką konstruktywną, stanowiącą alternatywę dla obojętnych na tę sprawę poczynań władz. Publicysta był zdania, że wobec mniejszości ukraińskiej należało działać jasno, konsekwentnie i kategorycznie, jak również spełniać jej żądania dotyczące życia narodowego i nie odkładać bieżących spraw na przyszłość38. Spełniać żądania, nie znaczyło jednak dawać cokolwiek z polskiego stanu posiadania. Nic nie tracąc, można było przecież pomóc mniejszości narodowej w rozwoju jej własnego dobrobytu ${ }^{39}$. Polska polityka konstruktywna przewidywała, że państwo polskie przejmuje inicjatywę z rąk świadomych Ukraińców galicyjskich, którzy prowokowali pewne niekorzystne dla wizerunku Polski w świecie zdarzenia (np. zamachy terrorystyczne czy sabotaż z 1930 r.). Ci Ukraińcy byli natomiast narzędziem polityki radzieckiej i niemieckiej. Władze polskie dostosowywały się tylko do zaistniałych sytuacji i działały bezmyślnie, nie licząc się z konsekwencjami swych ruchów (jak w przypadku pacyfikacji Galicji Wschodniej). Polityka ta miała przy tym organizować życie polityczne, narodowe i kulturalne mniejszości ukraińskiej, by mogła się ona w pełni rozwinąć jako naród. Jednym słowem, program ten miał przekonać Polaków i Ukraińców mieszkających w Galicji Wschodniej, iż mogą zgodnie żyć razem, rozwijając osobny stan posiadania ${ }^{40}$. Wspomaganie Ukraińców w tworzeniu ich życia narodowego w Galicji Wschodniej byłoby według Łosia niezwykle pożyteczne, jeśli chodzi o dobro Polski ${ }^{41}$. Pożyteczne byłoby też zwrócenie uwagi na problem nadwyrężonych stosunków polsko-ukraińskich polskiej opinii publicznej. Ta natomiast nie interesowała się tą sprawą, zaniedbywała ją, a co za tym idzie nie wywierała odpowiednich nacisków na rząd, przez co Rzeczpospolitą toczyła "chroniczna choroba, ropiejący rak nierozwiązanej sprawy ruskiej" 42 .

34 S. Łoś, O konstruktywną politykę..., s. 39-40; APL, AŁ, sygn. 473, S. Łoś, Reforma rolna na Południowym Wschodzie, k. 21; A. Bocheński, S. Łoś, W. Bączkowski, op. cit., s. 224.

35 Dane za: R. Torzecki, op. cit., s. 11.

36 APL, AŁ, sygn. 473, S. Łoś, Sprawa ukraińska w polityce polskiej, k. 28.

37 S. Łoś, O konstruktywną politykę..., s. 34-35.

38 Idem, Polityka mniejszościowa w Polsce, "Czas", 24 XII 1934, APL, At, sygn. 472, k. 22; APL, At, sygn. 473, S. Łoś, Uwagi o polityce szkolnej na terenie trzech województw południowo-wschodnich [rps, bd], k. 31.

39 „Teoria, że wzbogacić się można tylko o tyle, o ile ktoś inny zubożeje, jest prawdziwa tylko u bardzo nisko w rozwoju stojących murzynów, którzy nie potrafią jeszcze wychować krowy, więc muszą ją komuś ukraść. Murzyn, który potrafi już krowę wychować z cielęcia, może dojść do pięknej trzody bez najmniejszej krzywdy sąsiada". S. Łoś, O konstruktywną politykę..., s. 15.

40 Ibidem, s. 10; APL, At, sygn. 471, S. Łoś, Konstruktywna polityka polska na Rusi Czerwonej [mps, bd], k. 2 23; APL, At, sygn. 355, List do Tadeusza, (Niemce, 1931), k. 154.

41 „Znacznie wygodniejszym partnerem dla nas będzie ukraińskość zorganizowana i mająca rozbudowany stan posiadania, a więc ukraińskość odpowiedzialna, świadoma swych interesów i zatroskana o utrzymanie narodowego dorobku, niż ukraińskość podziemna, amorficzna, nie mająca nic do stracenia", S. Łoś, Odpowiedź na ankiete "Biuletynu», „Biuletyn Polsko-Ukraiński” nr 4 (243), 23.01.1938, s. 34

42 S. Łoś, Po oświadczeniu UNDO i UPR, „Czas”, 26 VII 1934, APL, AŁ, sygn. 472, k. 13. 
Odpowiedzialność leżała jednak nie tylko po stronie Polaków, ale także po stronie Ukraińców. Stanisław Łoś podkreślał, że muszą oni niezwłocznie określić własną rację stanu, która realizowałaby interesy ukraińskie, a nie niemieckie czy radzieckie. Bez niej mniejszość ta coraz bardziej się degradowała. Stosunek Ukraińców do narodu i państwa polskiego powinien być determinowany przez ich własną rację stanu, lecz musieliby oni pamiętać, że wszystko, co szkodziło Polsce, byłoby trucizną również dla nich. Nawet jeśli ukraińska racja stanu przebiegać miałaby równolegle z polską, Ukraińcy nie powinni jej zmieniać tylko z tego powodu ${ }^{43}$.

Stanisław Łoś sformułował postulaty ukraińskiej racji stanu w odniesieniu do Polski, które u podstaw miały rzeczywiste położenie narodu ukraińskiego w latach dwudziestych i trzydziestych. Faktem był brak wolnego państwa ukraińskiego oraz podzielenie jego narodu na cztery części: Ukraińców mieszkających w USRR, Polsce, Rumunii i Czechosłowacji. Łoś uważat, że największe nadzieje na stworzenie Ukrainy dawały dwa pierwsze odłamy. Komunizm panujący w Ukrainie sowieckiej absolutnie nie powinien być jednak rozciągnięty na cały naród - hrabia słusznie widział w nim zagrożenie. Granica uzyskana w traktacie ryskim była więc zbawienna, gdyż zapewniała drugiej silnej części narodu ukraińskiego szanse na rozwój na podwalinach kultury chrześcijańskiej, zachodniej. Ukraińcy haliccy byliby doskonale przygotowani do działania, gdyby "eksperyment komunistyczny" załamał się po wschodniej stronie Zbrucza. Wobec tego, skoro Galicja Wschodnia znajdowała się w Polsce, Ukraińcy tam mieszkający powinni to wykorzystać i maksymalnie doskonalić swój naród pod opieką państwa polskiego. Powinni oni dostosować się do istniejącej rzeczywistości i tworzyć swe życie narodowe w obrębie Rzeczypospolitej, a nie walczyć z nią. Publicysta podnosił w tym miejscu kwestię "misji Ukraińców halickich". Jako najsilniejszy odłam narodu ukraińskiego mieli oni za zadanie przygotować się do budowy w przyszłości wolnej Ukrainy za Dnieprem oraz szerzenia tam zachodnioeuropejskiej cywilizacji i kultury ${ }^{44}$.

Z polską polityką konstruktywną wiązał się nie tylko postulat określenia ukraińskiej racji stanu, ale także stosowanie się do zasad parytetu i paralelizmu narodowościowego. Wynikały one z sygnalizowanego już prawa do Galicji Wschodniej obu mieszkających w niej narodowości. Parytet to według Łosia „zapewnienie obu narodowościom zamieszkującym sporne terytorium [wrażenia], że żadna z nich nie będzie mogła być zmajoryzowana przez drugą" ${ }^{45}$. Stwierdzał on, że w Galicji Wschodniej zarówno Polacy jak i Ukraińcy powinni uważać się za autochtonów, lecz nie wywyższać się jedni ponad drugich. Dlatego też prawa języka polskiego i ukraińskiego muszą być zrównane ze sobą, również wszelkie napisy i obwieszczenia przeznaczone dla opinii publicznej powinny być pisane w obu tych językach. Co więcej, każdy mieszkaniec tego terenu powinien w zadowalający sposób znać i język polski, i ukraiński. W normalizacji stosunków między dwoma narodowościami w Galicji Wschodniej pomogłoby też oficjalne uznanie, otoczenie opieką oraz zrównanie w prawach z barwami polskimi barw błękitno-żółtych ${ }^{46}$.

Choć terytorium to znajdowało się w obrębie państwa polskiego, to galicyjscy Ukraińcy mieli pełne prawo, a nawet obowiązek, by współdecydować o jego losach. Dlatego też według Stanisława Łosia dobrym pomysłem byłoby wprowadzenie samorządu opartego

43 APL, At, sygn. V-2, t. 1, S. Łoś, [rps, b.t.] (sierpień 1932), k. 669; S. Łoś, O konstruktywną politykę..., s. 40.

44 Ibidem, s. 41-43; APL, At, sygn. V-1, t. 1, S. Łoś, Uwagi odnośnie do traktowania zagadnienia ukraińskiego w Polsce..., k. 292; APL, At, sygn. 355, List do Tadeusza (Niemce, 1931), k. 149; APL, At, sygn. 473, S. Łoś, Sprawa ukraińska w polityce polskiej, k. 29

45 S. Łoś, Pamiętniki - rozdział "Sprawa ukraińska” (mps ze zbiorów dr. inż. Marka Łosia), s. 50.

46 Idem, Odpowiedź na ankietę "Biuletynu», "Biuletyn Polsko-Ukraiński”, nr 4 (243), 23.01.1938, s. 34. 
na kuriach narodowościowych. Każda z kurii decydować miałaby o sprawach tylko dla niej istotnych, miałaby własny zbiór kompetencji i budżet. Obie narodowości rozwijałyby również swą strukturę socjalną i gospodarczą niezależnie od siebie, pod dyskretną ochroną państwa. Z władzami polskimi, każda z nacji, w sprawach jej tylko dotyczących, kontaktowałaby się bez pomocy czy nawet wiedzy drugiej. W sprawach ogólnych panowatby zaś parytet, wspólne podejmowanie decyzji. W biurokracji galicyjskiej dobrze byłoby zrównać liczbę urzędników polskich z ukraińskimi, a tam gdzie kierownikiem był Polak, jego zastępcą zostawałby Ukrainiec i na odwrót ${ }^{47}$.

Paralelizm narodowościowy oznaczał zaś równorzędność obu narodów oraz potrzebę budowy niezawisłego od siebie wspótistnienia. Paralelizm obejmować miał dziedziny najważniejsze dla życia mieszkańców Galicji Wschodniej: obrządek, oświatę i gospodarkę. Obok siebie powinny więc działać Kościoły rzymsko- i greckokatolicki, polska i ukraińska szkoła oraz kooperatywa. Dzięki tym działaniom złagodzono by napięcia narodowościowe na południowym-wschodzie oraz doprowadzono by do powiększenia stanu posiadania obu nacji, które jednak pracowałyby nie razem, a osobno. Dzięki tak zorganizowanemu życiu dzielnicy, bez przeszkód i bez konfliktów z władzami polskimi, karierę mogłaby robić ukraińska inteligencja. Wszak do tej pory popularni wśród swego narodu byli tylko ci, którzy postępowali wobec Rzeczypospolitej nielojalnie. Ukraińcy haliccy jako naród wytworzyliby przy tym pewien stan posiadania, który obawialiby się stracić w walce z państwem polskim. Zachowywaliby się przez to mniej buntowniczo, a bardziej racjonalnie ${ }^{48}$.

Mimo że Jan Stanisław Łoś pozytywnie odnosił się do samodzielnej pracy Ukraińców w Galicji Wschodniej, to raczej ostrożny był w kwestii przyznania autonomii trzem południowo-wschodnim województwom. Wynikało to ze sceptycyzmu wobec samych Ukraińców halickich. Publicysta obawiał się oddania całości władzy w ręce ukraińskie na terenach przygranicznych, gdyż nie miał pewności, czy działania tej grupy nie będą wymierzone w Rzeczpospolitą. Autonomiczność tego terenu uzależniał więc od sposobu sprawowania się przeważającej części jego mieszkańców. Jeśli bowiem Ukraińcy zachowywaliby się wobec państwa lojalnie, autonomia Galicji Wschodniej powinna się stać rzeczywistością ${ }^{49}$.

Stanisław Łoś już od 1921 r. żywił głęboką nadzieję na zmianę postawy Ukraińców galicyjskich tak, by można było podjąć z nimi rozmowy w sprawie ugody. Hrabia niewątpliwie pragnął porozumienia, jednak nie dążył do niego za wszelką cenę. Nie był również zwolennikiem umów wyłącznie na papierze, mawiając, że ugodę przyniesie życie. Uważał, że ugoda polsko-ukraińska wytworzy się samoistnie, gdy spełniona będzie wspomniana już zasada parytetu narodowościowego, a obie nacje w Galicji Wschodniej będą współpracować ze sobą ${ }^{50}$.

O Łosiu mówi się jako o nieoficjalnym ojcu umowy normalizacyjnej z 1935 r., podpisanej między rządem a Ukraińskim Zjednoczeniem Narodowo-Demokratycznym (UNDO). Łoś zaproponował w owej umowie wyborczej zasadę parytetu: ponieważ Galicja Wschodnia wysyłała do sejmu 30 posłów, powinno być to według hrabiego 15 Polaków i 15 Ukraińców, obdarzonych obustronnym zaufaniem ${ }^{51}$. Na tak ustalony skład obie narodowości

\section{$\cdots \cdots$}

47 Ibidem, s. 34; S. Łoś, Sytuacja międzynarodowa a Ukraińcy haliccy, Warszawa 1933, s. 23-24; idem, O konstruktywną polityke..., s. 40, idem, Pamiętniki..., s. 51; APL, At, sygn. V-1, t. 1, S. Łoś, [mps, bd, b.t.], k. 234.

48 S. Łoś, O konstruktywną polityke..., s. 16-17.

49 Idem, Bez niedopowiedzeń i nieporozumień, "Dzień Polski”, 16 XI 1932, APL, At, sygn. 472, k. 19; idem, Sytuacja i rola ziemiaństwa na południowym-wschodzie, "Dzień Polski”, 30 XII 1933, APL, At, sygn. 472, k. 16; APL, At, sygn. V-1, t. 1, S. Łoś, Uwagi odnośnie do traktowania zagadnienia ukraińskiego w Polsce..., k. 296.

50 S. Łoś, O konstruktywną politykę..., s. 17, 40.

51 Co ciekawe, wśród tego składu mógtby się znaleźć i Stanisław Łoś, jednak nie siegną on po mandat poselski. Tłumaczył to tym, iż poza parlamentem mógł swobodniej wyrażać swe poglądy w kwestii ukraińskiej, 
zagłosowałyby zgodnie. Ukraińcy mogli wysuwać swe żądania, jednak w sprawach państwowych musieli głosować jak Polacy. Publicysta był zadowolony z normalizacji, chwalit UNDO za zaufanie do władz polskich i za chęć współpracy ${ }^{52}$.

Z przytoczonych poglądów Stanisława Łosia na temat sprawy ukraińskiej w Polsce wynika, że nie był on bynajmniej „ukrainofilem”, jak określały go środowiska prawicowe, lecz zawsze kierował się interesem państwa polskiego. Będąc konserwatystą stojącym na straży polskiego stanu posiadania, hrabia Łoś nie obawiał się, że rozwój zamieszkującej Polskę mniejszości ukraińskiej zagrozi państwu. Uważał wręcz przeciwnie, że je wzmocni. Gdyby jego pomysły były realizowane przez polskie władze, być może udałoby się poprawić napięte stosunki polsko-ukraińskie i uniknąć tragedii, jaka rozegrała się między Polakami i Ukraińcami w czasie II wojny światowej. Ten specjalista zajmujący się kwestią ukraińską, doceniany przez obie strony, nie zdołał niestety zmienić toru polityki wobec Ukraińców prowadzonej przez kolejne gabinety rządu polskiego. Stało się tak z pewnością dlatego, że grup czy osób prywatnych podobnych hrabiemu, a więc obdarzonych zdroworozsądkowymi poglądami w kwestii ukraińskiej, było stanowczo za mało.

\section{JAN STANISLAW ŁOS'S VIEWS ON THE UKRAINIAN MINORITY IN THE SECOND POLISH REPUBLIC}

\section{Summary}

The Second Polish Republic's state policies were often unjust and shortsighted with respect to its Ukrainian minority. Happily, there were Poles whose activities were pro-Ukrainian. One of them was count Jan Stanisław Łoś (1890-1974), a diplomat and publicist representing conservative views. The author of the article attempts to analyse the political standpoint which Łoś presented in his journalistic writings, as well as in his other works on the issues concerning the Ukrainians inhabiting the following voivodships: Lviv, Tarnopol and Stanislav.

The author discusses Łos's views on crucial aspects of the minority's life: education and economy, as well as the politics of the Polish Republic in relation to the Ukrainians. In particular the following problems are dealt with: Ultraist schools, the Ukrainian university, land reform, Ukrainian cooperatives, as well as the sensitive issue of the assimilation politics of some Polish governments before 1939. Łoś suggested a few solutions, taking into account both the Polish state rationale and a just attitude to the Ukrainians. One can only regret that these proposals were not accepted. If they had been, one may speculate that they could have prevented the bloody Polish-Ukrainian conflict that broke out during World War II.

Keywords: Jan Stanisław Łoś, Ukrainian minority, Polish-Ukrainian relations

a przy tym nie popierał polityki Becka wobec III Rzeszy i ogólnie nie był zwolennikiem rządów pułkowników, S. Łoś, Pamiętniki..., s. 73-74.

52 Ibidem, s. 73; S. Łoś, Ukraińcy Haliccy w ciałach prawodawczych, "Czas”, nr 268, 30 IX 1935, APL, At, sygn. 472, k. 11. 